\title{
Determinants of Masks Purchasing Decisions
}

\author{
Lis Nurkhasanah ${ }^{1}$, dan Aprih Santoso ${ }^{2}$
}

1,2 Fakultas Ekonomi Universitas Semarang

Article Info

Article History:

Received

Revised

Accepted

Keywords:

price: product quality: promotion: purchase decisions

Kata Kunci:

harga: keputusan pembelian: kualitas produk: promosi

DOI:

Correspondence:

Name: Aprih Santoso

Email:aprihsantoso@usm.ac.id
Abstract

The purpose of the study was to analyze the effect of product quality, price perception and promotion on purchase decisions. Data collection techniques using questionnaires. The population in this study are consumers who buy onemed brand rubber masks at PT Inti Sumber Hasil Sempurna in Semarang for 3 times the purchase of each box 1 product and buy in 2017-2019 so that there are 192 people. The sampling technique to be used is accident sampling sampling technique according to the Slovin formula so sample of 66 respondents. This study uses multiple regression analysis techniques. The results of this study indicate the quality of the product. perceived price and promotion influence purchase decisions. Product quality variable on purchasing decisions is a significant positive effect. has a standardized estimate (regression weight) of 0.328 , (2) the variable price perception on purchasing decisions is a significant positive effect that has a standardized estimate (regression weight) of 0.159 , (3) the variable price perception on the purchase decisions is a significant positive effect has a standardized estimate (regression weight) of 0.601

\section{Abstraks}

Tujuan dari penelitian ini adalah untuk menganalisis pengaruh kualitas produk, persepsi harga dan promosi terhadap keputusan pembelian. Teknik pengumpulan data menggunakan kuesioner. Populasi dalam penelitian ini adalah konsumen yang membeli masker karet merek di PT Inti Sumber Hasil Sempurna di Semarang untuk 3 kali pembelian setiap produk kotak 1 dan membeli pada 2017-2019 sehingga ada 192 orang. Teknik pengambilan sampel yang akan digunakan adalah aksidental sampling menurut rumus Slovin sehingga sampel diperoleh sebanyak 66 responden. Penelitian ini menggunakan teknik analisis regresi berganda. Hasil penelitian ini menunjukkan kualitas produk. persepsi harga dan promosi mempengaruhi keputusan pembelian. Variabel kualitas produk pada keputusan pembelian adalah efek positif yang signifikan. memiliki estimasi standar (bobot regresi) sebesar 0,328, (2) persepsi harga variabel terhadap keputusan pembelian adalah pengaruh positif signifikan yang memiliki estimasi standar (bobot regresi) sebesar 0,159, (3) persepsi harga variabel pada keputusan pembelian adalah efek positif yang signifikan memiliki estimasi standar (bobot regresi) sebesar 0,601.
ISSN: 2355-9643 (Print) ISSN: 2460-3775 (on-line) 


\section{INTRODUCTION}

Purchasing decisions are very important to consider because purchasing decisions are things that are used by companies to create marketing strategies that will be carried out. Tjiptono (2020), a purchasing decisions is an act of consumers to want to buy or not to product. Of the various factors that influence consumers in purchasing a product or service, consumers usually always consider the quality, price and products that are already known by the public. That alternative consumer choices regarding the expected benefits and narrow the choice until the final alternative is chosen that can meet and satisfy his needs and desires. The purchase decision according to Schiffman and Kanuk (2014) is "the selection of an option from two or alter-native choices". Can be interpreted, the purchase decision is a decision of someone where he chose one of several alternative choices available.

Quality can be interpreted as the ability of a product both goods and services to meet consumer needs ". Product quality is very influential in marketing, if a product that is offered is of good quality and satisfies consumers, it will produce results in the form of increased demand turnover that can benefit the company. Efforts to produce products that really have good quality and avoid product failures outside the limits or standards set by the company, requires a quality control process. Product quality has dimensions that can be used to analyze the characteristics of a product. The product quality provided by the company is the right strategy to attract the attention of consumers (Tjiptono, 2020). This is supported by Amelia (2015), Shareef et al. (2008), Shaharudin et al. (2011), Ackaradejruangsri (2013), Tamunu dan Ferdinand (2014), Kalicharan (2014), Okta dan Ardani (2019) research which concluded that product quality has a positive influence on purchasing decisions.

In addition to product quality that takes precedence in a company, the price of the product must also not be ruled out. Because if the price determination in a product is not in accordance with the market then the possibility is very small for the product to be sold and sold in the market. Lupiyoadi (2014) states that the pricing strategy (pricing) is very significant in giving value to consumers and influencing the image of the product, as well as the consumer's decision to buy. The most important thing is the decision in price must be consistent with the marketing strategy and overall. In this case the price of the product and the quality of the product are expected to increase sales as much as possible to give consumers a decision to buy products offered in the market. Price is the only element of the marketing mix that provides income or income for the company, while the three other elements (product, distribution, and promotion) cause costs (expenses). In addition, the price is an element of the marketing mix that is flexible, meaning that it can be changed quickly (Tjiptono, 2020). Here it is assumed that all behavior is intentionally based on desires generated when consumers consciously and rationally choose one of the alternative actions available. Amelia (2015), Primantri dan Purnami (2017), Samosir dan Prayoga (2015) research of results that prices have a positive and significant influence on purchasing decisions.

Promotion is a direct flow of information or persuasion created to direct a person or organization to actions that create exchanges in marketing (Tjiptono, 2020). Good promotion is expected to establish communication between producers and consumers. Promotion is a one way flow of information or persuasion created to direct a person or organization to actions that create exchanges in marketing. Promotion is an effort or activity of a company in influencing actual and potential consumers so that they want to make a purchase of a product offered now or in the future (Kotler and Keller, 2016). Amelia (2015), Hariadi (2015), Widagdo (2011), Daud (2013), Primantri dan Purnami (2017) do research with the promotion results having a positive effect on purchase decisions.

One of Indonesia's medical equipment companies is PT. The Perfect Results Intisumber located at Jalan Gatot Subroto block 5 no. 12, Ngaliyan industrial area Semarang. One of the products produced is onemed brand masks. 
Table 1. Sales Data Of Onemed Brand Masks

\begin{tabular}{llll}
\hline Mask & 2016 & 2017 & 2018 \\
\hline Rubber mask & 25.744 & 23.822 & 22.110 \\
Rope mask & 18.432 & 18.522 & 16.834 \\
Hijab mask & 22.789 & 21.966 & 22.198 \\
\hline
\end{tabular}

Table 2. Sales Data Of Onemed Brand Rubber Masks

\begin{tabular}{llllllllll}
\hline Mont & \multicolumn{3}{c}{2016} & \multicolumn{3}{c}{2017} & & \multicolumn{3}{c}{2018} \\
& $\begin{array}{l}\text { Target } \\
\text { (box) }\end{array}$ & $\begin{array}{l}\text { Real } \\
\text { (box) }\end{array}$ & $\%$ & $\begin{array}{l}\text { Target } \\
\text { (box) }\end{array}$ & $\begin{array}{l}\text { Real } \\
\text { (box) }\end{array}$ & $\%$ & $\begin{array}{l}\text { Target } \\
\text { (box) }\end{array}$ & $\begin{array}{l}\text { Real } \\
\text { (box) }\end{array}$ & $\%$ \\
\hline Jan & 2,500 & 1.967 & 78,68 & 2.600 & 1.937 & 74,50 & 2.500 & 1.850 & 74,16 \\
Feb & 2.500 & 2.165 & 68,60 & 2.750 & 2.098 & 76,29 & 2.500 & 1.987 & 79,48 \\
March & 2.800 & 2.165 & 77,32 & 3.000 & 2.202 & 73,40 & 2.500 & 1.854 & 74,16 \\
April & 2.800 & 2.322 & 82,93 & 2.800 & 1.867 & 66,68 & 3.000 & 2.025 & 67,50 \\
May & 2.800 & 1.897 & 67,75 & 2.500 & 1.923 & 76,92 & 3.000 & 1.776 & 59,20 \\
June & 2.500 & 1.954 & 7816 & 2.500 & 1.956 & 78,24 & 3.000 & 1.832 & 61,07 \\
July & 2.700 & 2.143 & 79,37 & 2.700 & 1.793 & 66,41 & 2.800 & 1.890 & 67,50 \\
August & 3.000 & 2.298 & 76,60 & 2.900 & 2.142 & 73,86 & 2.800 & 1.834 & 65,50 \\
Sept & 3.000 & 2.249 & 74,97 & 2.900 & 2.042 & 70,41 & 2.700 & 1.967 & 72,85 \\
Oct & 3.000 & 2.396 & 79,87 & 3.000 & 2.031 & 67,70 & 2.700 & 1.723 & 63,81 \\
Nov & 3.000 & 2.298 & 76,60 & 3.000 & 1.903 & 63,43 & 2.700 & 1.712 & 63,41 \\
Dec & 3.000 & 1.890 & 63,00 & 3.000 & 1.928 & 64,27 & 2.700 & 1.656 & 61,33 \\
\hline Total & 33.600 & 25.744 & 76,62 & 33.650 & 23.822 & 70,79 & 32.900 & 22.110 & 67,20 \\
\hline
\end{tabular}

From the above data it can be seen that the sales of its special masks on rubber masks from 2016-2018 have decreased very dramatically. To find out the cause of the decline in the sale of rubber masks, a data search was carried out with the advantages and disadvantages of rubber mask products, price perceptions obtained from public opinion, and promotional factors that have been carried out by PT. Rubber masks that have a price of rp. 15,000/box are included in the category of affordable prices on onemed brands, but with such an affordable price does not make rubber masks increase in the number of sales.

\section{LITERATURE REVIEW}

\section{Purchasing Decisions}

Kotler and Keller (2016) states the purchase decisions is an act of consumers to want to buy or not to product. Of the various factors that influence consumers in purchasing a product or service, consumers usually always consider the quality, price and products that are already known by the public. Before consumers decide to buy, usually consumers go through several stages first, namely: (1) introduction of the problem. (2) information retrieval. (3) alternative evaluation. (4) buying decision or not. (5) post-purchase behavior. Ano- ther understanding of purchasing decisions according to Schiffman and Kanuk (2000) is "the selection of an option from two or alternative choices". Can be interpreted, the purchase decision is a decision of someone where he choose one of several alternative choices available. Lupiyoadi (2014) argues that five individual roles in a buying decision, namely: (1) Taking the initiative (initiator): individuals who have specific goods purchase initiatives or who have needs or desires but do not have the authority to do it themselves. (2) Influencers: individuals who influence the decision to buy intentionally or unintentionally. (3) Decider: individuals who decide whether to buy or not, what to buy, how to buy it, when and where to buy it. (4) Buyers: individuals who make actual purchases. (5) User (user): individuals who enjoy or use the product or service purchased.

\section{Consumer Decision Making Process}

According to Lamb et. al. (2001), there are se-veral stages in consumer decision making, namely: (1) Product. Introduction is the most important factor in making the purchase pro-cess, where buyers will recognize the pro-ducts needed. (2) Information seeking. A per-son always has an interest or drive to search for information. If the urge is strong and an object that can satisfy that need is available, then the consumer will be willing 
to buy it. (3) Evaluation of Alternatives, consumers will have the right choice and make careful alter-native choices to the products to be bought. (4) Buyer Decision, after the consumer has an alternative evaluation, the consumer will make a decision to buy. (5) Post-Purchase decisions, after a consumer decides to buy a product, the consumer will judge whether or not fasting over the purchase.

\section{Product Quality}

Lupiyoadi (2014) states that "Quality is a combination of nature and characteristics that determine the extent to which outputs can meet customer requirements". Tjiptono (2020) states "Quality can be interpreted as the ability of a product both goods and services to meet consumer needs". Kotler and Keller (2016) stating "Improving quality or quality in an organization can have a dramatic impact on the hierarchical structure. One reason is that a component of an effective quality pro-gram uses self-directed work teams to increase productivity". From the opinions of the experts above, it can be concluded that qua-lity refers to the definition of meeting certain standards or requirements, quality also has an understanding as an effort to make improvements and improvements continuously in meeting customer needs so as to satisfy customers.

Tjiptono (2020) revealed there are eight dimensions of product quality, namely: (1) Performance. Performance is the main characteristic or function of a product. This is the main benefit or efficacy of the products we buy. Usually this is our first consideration in buying a product. (2) Product Features. Dimensions of features are additional characteristics or characteristics that complement the basic benefits of a product. Features are optional for consumers. When the main benefits are standard, features are often added. The idea is that features can improve product quality if competitors do not have them. (3) Reliability. The reliability dimension is the opportunity for a product to be free from failures when carrying out its functions. (4) Conformity with specifications (conformance to specification). Conformance is the conformity of product performance with the stated standards of a product. This is a kind of "promise" that must be fulfilled by the product. Products that have quality from this dimension mean that they are in accordance with the standards. (5) Durability. Durability indicates the age of the product, i.e. the amount of use of a product before the product is replaced or damaged. The longer the durability of course the more durable, durable products will be perceived as being of higher quality than products that are quickly used up or replaced quickly. (6) Ability to be improved (serviceability). In accordance with its meaning, here the product quality is determined on the basis of ability to be improved: easy, fast, and competent. Products that can be repaired are certainly of higher quality compared to products that are not or difficult to repair. (7) Beauty (aestethic). The beauty involves the appearance of products that can make consumers like. This is often done in the form of product design or packaging. Some brands are updated "face" to be more beautiful in the eyes of consumers. (8) Perceived quality. This concerns the consumer's assessment of the image, brand, or advertisement. Famous branded products are usually perceived as higher quality than brands that are not heard.

Kotler and Keller (2016) states the objectives of product quality are as follows: (1) Make sure that the products produced reach the set standards. (2) Ensure that inspection costs can be as small as possible. (3) Ensuring that the design costs of a particular production are as small as possible (4) Ensuring that the production costs can be as low as possible. The definition of product quality is to reflect the ability of the product to carry out its duties which include durability, reliability or progress, strength, ease of packaging and product repairs and other characteristics (Kotler and Armstrong, 2014).

\section{Price Perception}

Price is the amount of money (plus some products if possible) needed to get a combination of products and services (Kotler and Keller, 2016). Price is also defined as an exchange rate for benefits arising from certain goods or services for someone. The higher the perceived benefits of consumers of certain products or services, the higher the exchange rate of these goods and services for consumers and the greater the exchange tool that is sacrificed. From the consumer's point of view, 
price is often used as an indicator of value when the price is related to the perceived benefits of goods or services. Thus it can be concluded that at a certain price level, if the benefits perceived by consumers increase, the value will increase as well (Tjiptono (2020). Often also in determining the value of an item or service, consumers compare the ability of an item or service to meet their needs with the ability of substitute goods or services. that consumers expect prices that are commensurate with the quality of the product from their purchases. Tjiptono (2020), there are four types of pricing objectives, namely: (1) GoalOriented Goals. The assumption of classical economic theory states that each company always chooses the price that can produce the highest profit. This goal is known as profit maximization. (2) Volume-Oriented Goals. In addition to profit-oriented goals, there are also companies that fix prices based on specific volume-oriented goals or commonly known as volume pricing objectives. (3) Objective Oriented. The image of a company can be formed through a pricing strategy. Companies can set high prices to form or maintain a prestigious image. Meanwhile low prices can be used to form a certain value, for example by providing guarantees that the price is the lowest price in a certain region. (4) The Purpose of Price Stabilization. In a market where consumers are very sensitive to prices, if a company lowers its prices, its competitors must reduce their prices. Conditions like this that underlie the formation of price stabilization goals in certain industries whose products are standardized. The purpose of this stabilization is done by setting prices for a stable relationship between the price of a company and the price of an industry leader. Kotler and Armstrong (2014), within the variable price there are several main elements of price activity which include price lists, discounts, discounted prices, and payment periods. Kotler and Armstrong (2014) state that, there are four indicators that characterize prices, namely: Affordability of prices, conformity of prices to the quality of products, price competitiveness, suitability of prices with benefits.

\section{Promotion}

Tjiptono (2020) that promotion is a form of marketing communication, what is meant by marketing communication is marketing activities that seek to disseminate information, influence or persuade, and or increase the target market for companies and their products to be willing to accept, buy and be loyal to the products offered company concerned. Promotion objectives according to Kotler and Armstrong (2014), namely: (1) Encouraging short-term customer purchases or improving long-term customer relationships. (2) Encouraging retailers to sell new goods and provide more inventory. (3) Advertise company products and provide more shelf space. (4) For salespeople, it is useful to get more sales force support for old or new products or to encourage salespeople to get new customers.

The five main means of promotion according to Kotler and Armstrong (2014), are: (1) Advertising (advertising). All forms of paid non-personal presentations and promotion of ideas, goods, or services with certain sponsors. According to Kotler and Armstrong (2014), advertising goals are certain communication tasks that are achieved with a specific target audience over a certain period of time. (2) Sales promotion Short-term incentives to encourage the purchase or sale of products or services. According to Kotler and Armstrong (2014), there are many tools that can be used to achieve sales promotion objectives, namely: (a) Consumer promotion tools Including product samples, coupons, cash returns, special prices, premiums, special items of advertisements, sweepstakes, and games. (b) Trade promotion tools Persuade intermediary sellers to sell a brand, provide shelf space, promote the brand in advertisements, and ultimately offer it to consumers. (c) Business promotion tools Sales promotion tools used to generate business direction, encourage purchases, value customers, and motivate salespeople. Here the company focuses on two additional tools for major business promotions, conventions and trade shows. (3) Public relations Establish good relations with various groups to get the desired publicity, build a good corporate image, and handle or deal with unpleasant rumors, news and events. (4) Personal selling. Personal presentations by company sales people for the purpose of generating sales and building customer relationships. According to Kotler and Armstrong (2014) personal selling 
is one of the oldest professions in the world. People who make sales get many designations, namely salespeople, district managers, account executives, agents, sales consultants, etc. Many companies use personal sales because it can function as a bridge between the com-pany and its customers.

In many cases, personal sales represent two employers, the seller and the buyer. Direct marketing Direct relationships with carefully targeted individual consumers to get an immediate response and build lasting customer relationships use of direct mail, telephone, direct response television, e-mail, Internet and other means of communication directly with certain consumers.

\section{Relationship Between Variables and Hypothesis Formulation}

\section{Effect of Product Quality on Purchasing} Decisions

Product quality is highly considered by consumers. Consumers want the best quality products on products that have been purchased. Kotler and Keller (2016) the meaning of product quality is the characteristics and characteristics of an item or service that affects its ability to satisfy the expressed needs implied. Quality has a direct impact on product or service performance, therefore quality is closely related to value and customer satisfaction. Based on a review of previous research conducted by Amelia (2015), Shareef et al. (2008), Shaharudin et al. (2011), Ackaradejruangsri (2013), Tamunu dan Ferdinand (2014), Kalicharan (2014), Okta dan Ardani (2019) can be concluded that product quality has a positive and significant effect on purchasing decision. Based on the description, so in this study a hypothesis can be formulated as follows:

$\mathrm{H}_{1}$ : Product quality has a positive and significant influence on purchasing decisions

Effect of Price Perception on Purchasing Decisions

The role of prices is inseparable from the process of buying and selling a product or service. Prices help consumers to determine whether someone will buy goods or not. Kotler and Armstrong (2014) state that price is the amount of money that a customer must pay to obtain a product. Prices are things that can be controlled and determine whether or not a product is accepted by consumers. Cheap or high price of a product is very relative in nature. Thus the right pricing strategy is needed. Based on a review of research conducted by Amelia (2015), Primantri dan Purnami (2017), Samosir dan Prayoga (2015) can be concluded that the independent variable namely price has a positive and significant effect of the dependent variable, namely the purchase decision. Based on the description above, the hypothesis can be formulated as follows:

H2: Price perception has a positive and significant influence on purchasing decisions.

Effect of Promotion on Purchasing Decisions

Promotion becomes a core ingredient in marketing campaigns, consist of a collection of incentive tools, mostly short-term designed to stimulate faster or greater purchases of certain products or services by consumers or commerce (Kotler and Keller, 2016). Promotion is an important aspect of marketing management and is often said to be an ongoing process. With promotion causes people who were not previously interested in buying a product will become interested and try the product so that consumers make a purchase. Based on a review of research conducted by Amelia (2015), Hariadi (2015), Widagdo (2011), Daud (2013), Primantri dan Purnami (2017) that there is a significant influence between variables promotion on purchasing decisions Based on the description above, then the hypothesis can be formulated as follows:

$\mathrm{H}_{3}$ : Promotion Has A Positive And Significant Influence On Purchasing Decisions.

\section{RESEARCH METHODS}

The population in this study are consumers who buy onemed brand rubber masks at PT Inti Sumber Hasil Sempurna in Semarang for 3 times the purchase of each box 1 product and buy in 2017-2019 so that there are 192 people. The sampling technique to be used is accident sampling sampling technique according to the Slovin formula (Sugiyono, 2017), namely:

$\mathrm{n}=\frac{\mathrm{N}}{1+\left(\mathrm{Ne}^{2}\right)}$ 


$$
\begin{array}{r}
n=\frac{192}{1+\left(192 \times 0.1^{2}\right)} \\
n=66
\end{array}
$$

\section{Analysis Method}

\section{Validity test}

Ferdinand (2014) states the validity test of a measuring instrument is shown from its ability to measure what should be measured. If all instruments from the questionnaire tested are appropriate, then the instrument is said to be valid. The validity test research criteria is if $r$ count $>r$ table, then the questionnaire items are valid. If $r$ arithmetic $<r$ table, it is said that the questionnaire items are invalid.

\section{Reliability Test}

Ferdinand (2014) states a scale or measuring instrument for data and the resulting data is called reliable or reliable if the instrument consistently raises the same results every time a measurement is taken. to find out the questionnaire is reliable, it will be tested the reliability of the questionnaire. The decision making method in the reliability test is using a limit of 0.60 which means that a variable is said to be reliable if the value indicates Cronbach's Alpha is greater than 0.60.

\section{Normality test}

Ferdinand (2014) states the data normality test aims to test whether in the regression model, the residual variable has a normal distribution. To test the data collected normal distribution or can not be done with the Kolmogorov Smirnov test method. The normal testing method is whether the data distribution is carried out by looking at the significance value of the variable, if significant is greater than 0.05 , then it indicates that the data distribution has been normally distributed.

\section{Multicollinearity Test}

Ferdinand (2014) states the multicollinearity test aims to test whether the regression model found a correlation between independent variables. There are several ways to test whether or not there is multicollinearity in the regression model, in this test researchers used a correlation matrix analysis between independent variables by looking at the value of Variance Inflation Factor (VIF). If the VIF is less than 10, this means there is no multicollinearity in the regression model used in the study.

\section{Heteroskedacity Test}

Ferdinand (2014) states the heteroskedacity test aims to test whether in a regression model there is an inequality of variance from residuals from one observation to another. In this study the glacier test was used as the basis for decision making, that is, if the independent variable was significantly less than 0.05 statistically affecting the dependent variable, then heterokedastasis occurred. If the independent variable is significantly greater than 0.05 statistically it does not affect the dependent variable, then heterokedasticity does not occur in the study.

\section{Multiple Linear Regression}

Ferdinand (2014) states that multiple regression is performed on models of more than one independent variable, to determine its effect on the dependent variable. In multiple regression independent variables are taken into account their effect on the dependent variable. So the regression equation is as follows :

Purchase Decision $=$ b1 $($ Product Quality $)+$ b2 (Price Perception) + b3 (Promotion)

$t$ test

Ferdinand (2014) states that the hypothesis test is used to test the effect of independent variables that is persistently to the dependent variable, namely the purchase decision. Test criteria with significant numbers are as follows: (1) If the probability is $<0.05$, then Ho is rejected or Ha is accepted, meaning that there is a significant influence between the bebad variable on the dependent variable on a partial basis. (2) If the probability is $>0.05$, then Ho is accepted or $\mathrm{Ha}$ is rejected, meaning that there is no significant effect between the independent variable on the partially dependent variable.

\section{F test}

The accuracy test of the model is used to find out whether the model can be used to predict variables while the basis for decision making by using significance numbers, namely: (1) If the probability (significance)> 0.05 (a) 
means the hypothesis is not proven then $\mathrm{HO}$ is accepted Ha is rejected so the result incorrect. (2) If the probability (significance) $<0.05$ (a) means the hypothesis is proven then $\mathrm{H} 0$ is rejected and $\mathrm{Ha}$ is accepted so the results are right.

\section{Coefficient of Determination}

Ferdinand (2014) states that the analysis of Adjust R square or coefficient of determination is used to find out how much influence the independent variable has in explaining the variation of the dependent variable in the study. The coefficient of determination is between zero and one. The ability of independent variables that can only explain a limited variation of the dependent variable will be shown by Adjust $R$ square or a small value of R2. While the independent variables that almost all provide the information needed to predict variations in the dependent variable will show Adjust R square or R2 values close to one.

\section{RESULT AND DISCUSSION}

Validity Analysis

Table 3. Validity Test

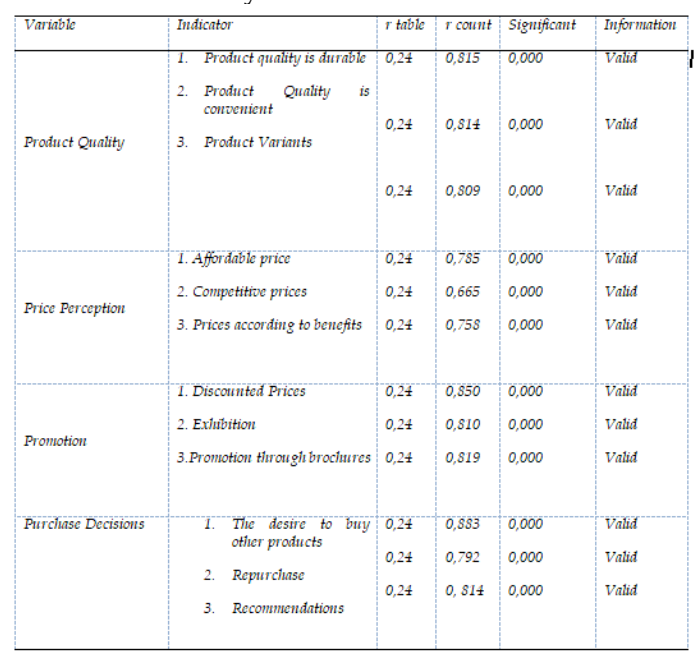

Based on the above table, all indicator items are declared valid because the calculated value is greater than the value, which is greater than 0.24 with a significance level of less than 0.05 . So that, each indicator on each of these variables can be done in the next calculation.
Table 4. Reliability Test Result

\begin{tabular}{|l|l|l|l|}
\hline Variable & Cronbach's Alpha & Reliability Standart & Information \\
\hline Product Quality & 0,831 & 0,70 & Reliable \\
Price Perception & 0,796 & 0,70 & Reliable \\
Promotion & 0,837 & 0,70 & Reliable \\
Purchase Decisions & 0,839 & 0,70 & Reliable \\
\hline & & & \\
\hline
\end{tabular}

Table 5. Normality Test

\begin{tabular}{|c|c|c|}
\hline \multicolumn{3}{|c|}{ One-Sample Kolmogorov-Smirnov Test } \\
\hline & & $\begin{array}{l}\text { Unstandardized } \\
\text { Residual }\end{array}$ \\
\hline$N$ & & 66 \\
\hline \multirow{2}{*}{ Normal Parameters $5^{a, b}$} & Mean & 0000000 \\
\hline & Std Deviation & 175171505 \\
\hline \multirow{3}{*}{ Most Extreme Differences } & Absolute & $095^{--}$ \\
\hline & Positive & 095 \\
\hline & Negative &,- 055 \\
\hline \multicolumn{2}{|l|}{ Kolmogorov-Smirnov Z } & 775 \\
\hline \multicolumn{2}{|l|}{ Asymp. Sig. (2-tailed) } & 586 \\
\hline \multicolumn{3}{|c|}{ a. Test distribution is Normal. } \\
\hline
\end{tabular}

Based on the results of normality testing data on a sample of 66 respondents showed that for testing the variables of product quality, price perception, and promotion of purchasing decisions normally distributed. Evidenced by the significance value that has exceeded the error rate limit of $0.586>0.05$. Thus testing on research variables is normally distributed and can be continued on further testing.

\section{Heteroscedasticity Test}

Heteroscedasticity test aims to test whether in the regression model there is an inequality of variance from the residuals of one observation to another. If the variance from one observation residual to another observation remains, then it is called homoscedasticity and if different is called heteroscedasticity. A good regression model is one that does not occur heteroscedasticity. If the significance value is greater than 0.05 , then heteroscedasticity does not occur and if the significance value is less than 0.05 , heteroscedasticity occurs. 
Table 6. Heteroscedasticity Test

\begin{tabular}{|c|c|c|c|c|c|c|}
\hline & & & Coefficientst & & & \\
\hline Model & & Unstan. & eed Cocfficients & $\begin{array}{l}\text { Standardized } \\
\text { Coefficients }\end{array}$ & $T$ & Sig. \\
\hline & (Constant) & 1,973 & 655 & & 3,013 & 004 \\
\hline & Product Quality & .008 & 073 & .025 & 116 & 908 \\
\hline & Price Perception & 1086 & .052 & 209 & 1,632 & 108 \\
\hline & Promotion & 009 & .067 & .028 & 131 & 896 \\
\hline
\end{tabular}

Multicollinearity Test

Table 7. Multicollinearity Test

\begin{tabular}{|l|l|l|l|}
\hline \multirow{2}{*}{ Variable } & \multicolumn{2}{|c|}{ Collinearity Statistic } & \multicolumn{2}{l|}{ Information } \\
\cline { 2 - 4 } & Tolerance & VIF & \\
\hline Product Quality & 0,326 & 3,063 & no multicollinearity \\
\hline Price Perception & 0,931 & 1,074 & no multicollinearity \\
\hline Promotion & 0,337 & 2,969 & no multicollinearity \\
\hline
\end{tabular}

Based on the table above, it shows that all tolerance values $>0.10$ while VIF values $<10$ so that there is no multicollinearity between independent variables in the regression model.

\section{Multiple Linear Regression Analysis}

Table 8. Multiple Linear Regression Analysis

\begin{tabular}{|c|c|c|c|c|c|c|}
\hline & & & \multicolumn{4}{|c|}{ Coefficiontst } \\
\hline & \multirow[t]{2}{*}{ Model } & \multicolumn{2}{|c|}{ Unstandardized Coefficients } & \multirow{2}{*}{$\begin{array}{c}\begin{array}{c}\text { Standardized } \\
\text { Coefficients }\end{array} \\
\text { Beta }\end{array}$} & \multirow[t]{2}{*}{$t$} & \multirow[t]{2}{*}{ Sig. } \\
\hline & & B & Stad. Error & & & \\
\hline \multirow{4}{*}{1} & (Constant) & 3,336 & 1,010 & & 3,303 & .002 \\
\hline & Product Quality &, 332 & ,112 &, 328 & 2,954 & .00 \\
\hline & Price Perception &, 195 & .081 &, 159 & 2,410 & 019 \\
\hline & Promotion & .566 & 103 &, 601 & 5,498 & .000 \\
\hline
\end{tabular}

The results of the regression equation in the table above can be stated in the multiple linear regression equation as follows:

Purchase Decision $=0.328$ (Product Quality) + 0.159 (Price Perception) + 0.601 (Promotion)

The results of the regression equation can be interpreted as follows:

1. Variable product quality has a positive effect meaning the higher the quality of the product, the higher the consumer's desire to make a purchase.

2. The variable price perception has a positive effect means the more affordable the price, the more it will increase consumers to make purchases.

3. Promotional variables have a positive effect, meaning that the more often promotions are made, the more consumers will make purchases.
Based on the results of multiple linear regression analysis shows that the promotion variable provides the greatest influence on purchasing decisions.

Table 9. t-Test

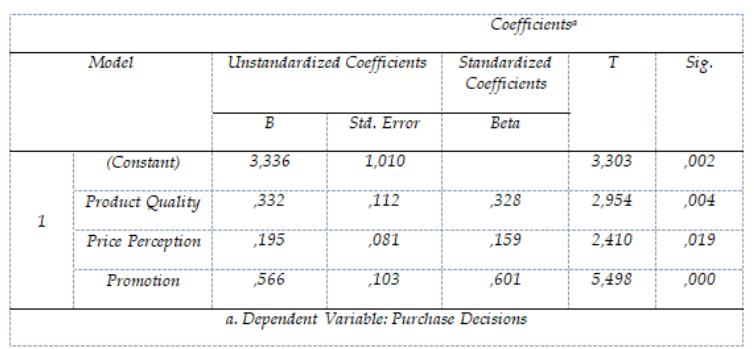

1. Product Quality

The results of product quality testing with a significance probability of $0.004<0.05$, then $\mathrm{Ha}$ is accepted, which means that product quality has a positive effect on purchasing decisions.

2. Price Perception

The results of testing price perceptions with a significance probability of 0.019 $<0.05$, Ha is accepted, which means that price perceptions have a positive effect on purchasing decisions

3. Promotion

Promotion test results with a significance probability of $0,000<0.05$, then $\mathrm{Ha}$ is accepted, which means the promotion has a positive effect on purchasing decisions.

Table 10. F Test

\begin{tabular}{|c|c|c|c|c|c|c|}
\hline & & & \multicolumn{4}{|c|}{ ANOVA $A^{a}$} \\
\hline \multicolumn{2}{|r|}{ Model } & Sum of Squares & $d f$ & Mean Square & $F$ & Sig. \\
\hline \multirow{3}{*}{1} & Regression & 259,235 & 3 & 86,412 & 62,139 & $.000^{b}$ \\
\hline & Residual & 86,219 & 62 & 1,391 & & \\
\hline & Total & 345,455 & 65 & & & \\
\hline & & a. Dependent V & ble: $P$ & hase Decoisions & & \\
\hline
\end{tabular}

Based on the $\mathrm{f}$ test results with a significance probability of $0,000<0.05$, ha is accepted, which means product quality, price percep-tion, and promotion have a simultaneous effect on purchasing decisions.

The calculation results above show the Ad-justed $\mathrm{R}$ Square value of 0.738 . This means that $73.8 \%$ of the variation in the purchase de-cision variable is explained by variables of product quality, price perception, and promo-tion while the remaining $26.2 \%$ is explained by other variables outside the model, such as: location, brand image and others. 
Table 11. Determination Test

\begin{tabular}{|c|c|c|c|c|}
\hline \multicolumn{5}{|c|}{ Model Summary } \\
\hline Model & $R$ & R Square & $\begin{array}{c}\text { Adjusted R } \\
\text { Square }\end{array}$ & $\begin{array}{c}\text { Std. Error of the } \\
\text { Estimate }\end{array}$ \\
\hline 1 &, $866^{a}$ &, 750 &, 738 & 1,179 \\
\hline a. Predictors: (Constant), Promotion, Price Perception, Product \\
Quality
\end{tabular}

\section{Effect of Product Quality on Purchasing Decisions}

Based on research results, it is evident that product quality has a positive and significant influence on purchasing decisions. In other words, the higher the quality of the product, the more consumers will make a purchase. The existence of good and reliable product quality can increase the likelihood of purchasing decisions. This is also supported by research from Amelia (2015), Shareef et al. (2008), Shaharudin et al. (2011), Ackaradejruangsri (2013), Tamunu and Ferdinand (2014), Kalicharan (2014), Okta and Ardani (2019) which showed that product quality had a positive and significant effect on purchasing decisions.

The increasingly fierce competition that exists today companies are required to offer quality products and are able to have more value, so different from competitive products, product quality is one of the considerations of consumers before buying a product. Product quality is determined by the durability, function and usefulness, with a good and reliable product quality, consumers will always remember the product. However, this study contradicts the research results of Rawung et al. (2015) and Budiyanto et al. (2016) which states that product quality has no effect on purchasing decisions.

\section{Effect of Price Perception on Purchasing Decisions}

Based on the results of the study, it is evident that price perception has a positive and significant influence on purchasing decisions. In other words, the more affordable the price, the more consumers will make a purchase. Low prices can increase the likelihood of a buying decision. This is also supported by research from Amelia (2015), Primantri and Purnami (2017), Samosir and Prayoga (2015) which shows that prices have a posi- tive and significant effect on purchasing decisions. The effect of prices on a product is also very important. If the price is low, the demand for the product offered increases and if the price of the product is higher, the demand for the product will be lower. Appropriate pricing will get the most attention from consumers, then the selection of a product will be dropped on the product. The company sets the price due to various considerations, in which the price is adjusted according to the quality of existing products. However, this study contradicts the research results of Mandey (2013), Yazia (2014) and Deisy et. al. (2015) which states that the price has no effect on purchasing decisions.

\section{Effect of Promotion on Purchasing Decisions}

Based on research results, it is evident that promotion has a positive and significant influence on purchasing decisions. In other words that the more often the promotion, the more consumers will make a purchase.

Promotional activities can increase the likelihood of buying decisions. This is also supported by research from Amelia (2015), Hariadi (2015), Widagdo (2011), Daud (2013), Primantri and Purnami (2017) who showed that promotion had a positive and significant effect on purchasing decisions. The company's ability to communicate products to consumers through promotional activities is also an important thing. Promotion is a company activity to highlight product features and persuade consumers to buy. The promotion strategy combines advertising, individual sales, sales promotion and publicity into an integrated program to communicate with buyers and others who will ultimately influence purchasing decisions. To further introduce their products, and carry out promotional activities to attract consumer buying interest and are based on information about the advantages and advantages of a product, arranged in such a way as to cause interest in those who see or hear it. Thus it will affect consumer buying behavior towards the product. However, this study contradicts the results of research by Budiyanto et. al. (2016) states that promotion has no effect on purchasing decisions. 


\section{CONCLUSION}

Product quality variables have a positive effect on purchase dedisions. Providing understanding that the higher the product quality, the higher the consumer's desire to make a purchase. Price perception variable has a positive effect on purchase dedisions. Providing understanding that the more affordable the price, the more consumers will make a purchase. Promotional variables have a positive effect on purchase dedisions. Providing understanding that the more often the promotion is carried out, the more consumers will make a purchase.

In improving product quality on the durability indicator, the durable product has the lowest value compared to other indicators, it is recommended that PT. Intisumber Hasil Perfect Semarang provide a more durable material to the durability of rubber mask products so that it can compete with other products. In increasing the price perception on the indicator of price competitiveness has a lower value than other indicators, it is recommended that PT. Intisumber Hasil Perfect Semarang provide discounts to attract consumer purchasing power. In increasing the promotion of the product exhibition indicator has a lower value than other indicators, it is recommended that PT Intisumber Hasil Perfect Semarang conduct product exhibitions in various regions so that people more easily know the onemed rubber mask products. In improving purchasing decisions on indicators of lower purchasing power com-pared to other indicators, it is recommended that PT. Intisumber Hasil Sempurna Semarang provide samples of onemed brand rubber mask products to further convince consumers to make a purchase.

In this study using quantitative research so that the results given ignore the details of the social context in question. In quantitative research has the potential for structural bias because the formulation of the problem usually reflects the interests of researchers without considering the actual problems faced by respondents, and the results of the study have a limited explanation of the quality of numerical descriptions and lack of detail in collating aspects of respondents' perceptions.

Future studies can use other variables that have not been used in this study and try to use qualitative research methods because the preferred qualitative research is to highlight the quality of the analytical description and the results of the development of problems related to increasing purchasing decisions.

\section{REFERENCE}

Ackaradejruangsri, Pajaree. (2013). The effect of product quality atttributes on Thai's consumer buying decisions. Journal of Asia Pacific Studies.. 3 (3) : 14-24.

Amelia, L. R. 2015. The Influence of Marketing Mix Variables on Purchase Decision and Customer Satisfaction (Case Study of Customer of Vitiara Rent Car Malang). Jurnal Administrasi Bisnis, 28 (2) : 1-10

Daud, D. (2013). Promosi dan kualitas layanan pengaruhnya terhadap keputusan konsumen menggunakan jasa pembiayaan pada PT. Bess Finance Manado. Jurnal Riset Ekonomi, Manajemen, Bisnis Dan Akuntansi, 1(4) : 51-59. https://ejournal.unsrat.ac.id/index.ph $\mathrm{p} / \mathrm{emba} /$ article/view/2563

Ferdinand, Augusty. 2014. Metode Penelitian Manajemen. BP Universitas Diponegoro. Semarang.

Hariadi, D. (2015). Pengaruh produk, harga, promosi dan distribusi Terhadap keputusan pembelian konsumen Pada produk projector microvision. Jurnal Ilmu \& Riset Manajemen, 1(8) : 1-11

Kaharu, D. (2016). Pengaruh Gaya Hidup, Promosi, Dan Kualitas Produk Terhadap Keputusan Pembelian Pada Cosmic. Jurnal Ilmu \& Riset Manajemen, 5 (3) : 1-24

Kalicharan, H.D. (2014). The effect and influence of country-of-origin on consumer's perception of product quality and purchasing intentions. International Business and Eco-nomic Research Journal, 13 (5) : 897-902

Khanfar, D. Iyad A. 2016. The Effect of Promotion Mix Elements on Consumers Buying Decisions of Mobile Service: The case of Umniah Telecommunication Company at Zarqa city-Jordan. European Journal of Business and Management, 8 (5): 2222- 
1905.

Kodu, S. (2013). Harga, Kualitas Produk dan Kualitas Pelayanan Pengaruhnya Terhadap Keputusan Pembelian Mobil Toyota Avanza, Jurnal EMBA 1251, 1 (3): 1251-1259.

Kotler, Philip and Kevin Lane Keller, 2016. Marketing Managemen, 15th Edition, Pearson Education,Inc.

Kotler, Philip dan Gary Armstrong, (2014). Marketing Management. Edisi Keempat belas. Global Edition : Pearson Edition.

Kurniawan, D., dan Kunto, Y.S. 2013. Pengaruh Promosi dan Store Atmosphere Terhadap Impulse Buying dengan Shopping Emotional Sebagai Variabel Intervening Studi Kasus Di Matahari Department Store Cabang Supermall Surabaya. Jurnal Manajemen Pemasaran Petra, 1 (2): 1-8

Kusdyah, I. 2012. Persepsi Harga, Persepsi Merek, Persepsi Nilai, dan Keinginan Pembelian Ulang Jasa Clinic Kesehatan (Studi Kasus Erha Clinic Surabaya). Jurnal Manajemen Pemasaran, 7(1): 2532

Lamb, CW., Joseph F. Hair, Carl McDaniel. 2001. Pemasaran, Edisi pertama. Salemba Empat. Jakarta

Lupiyoadi, Rambat. 2014. Manajemen Pemasaran Jasa Berbasis Kompetensi. Edisi ke-3. Jakarta: Salemba Empat.

Megarita, G., dan Tony S. (2014). Pengaruh kualitas produk terhadap citra merek dan dampaknya terhadap perilaku pembelian produk susu merek ultra milk di Jakarta Utara. Jurnal Manajemen Pemasaran. 4 (1) : 57-69

Okta, KAR., Ardani, IGAKS. (2019). Pengaruh Kualitas Produk Terhadap Keputusan Pembelian Handphone Nokia Dengan Citra Merek Sebagai Pemediasi. EJurnal Manajemen Unud, 8 (3) : 13741400.

Primantri, AABDA.,dan Purnam, NM. (2017). Pengaruh Promosi, Gaya Hidup, Dan Persepsi Harga Terhadap Keputusan Penggunaan Taksi Online Blue Bird. Jurnal Ilmiah Manajemen \& Akuntansi 23 (2) : 75 - 88

Samosir, Charlie Bernando Halomoan dan Arief Bowo Prayoga K. (2015). Jurnal Pengaruh Persepsi Harga dan Promosi
Terhadap Keputusan Pembelian Konsumen Produk Enervon-C. Jurnal Ilmiah Manajemen dan Bisnis, 1(3). 4758

Schiffman, Leon dan Kanuk, Leslie L. (2014). Perilaku Konsumen. Jakarta: IndeksSetiadi, N.J. (2013). Perilaku Konsumen: Perspektif Kontemporer pada Motif, Tujuan dan Keinginan Konsumen. Jakarta:Kencana.

Shaharudin, M.R., Suhardi W.M., Anita A.H., Maznah W.O., and Etty H.H. (2011). The relationship between product quality and purchase intention: The case Malaysia's national motorcycle/scooter manufacturer. African Journal of Business Management, 5 (20) : 8163-8176.

Shareef, M.A., Uma K., and Vinod K. (2008). Role of different electronic- commerce (EC) quality factors on purchase decision: A developing country perspective. Journal of Electronic Research. 9 (2) : 92- 113

Sugiyono. (2017). Metode Penelitian Kuantitatif, Kualitatif, dan R\&D. Bandung: Alfabeta, CV

Tampanatu, G. A., Lumanauw, B., \& Tumbuan, W. J. (2014). Analisis Gaya Hidup, Kualitas Prdoduk Terhadap Keputusan Pembelian Konsumen Di Matahari Department Store Mega Trade Center Manado. Jurnal Riset Ekonomi, Manajemen, Bisnis Dan Akuntansi, 2 (3) : 807-816

Tamunu, M., Ferdinand T. (2014). Analyzing the influence of price and product quality on buying decision honda matic motorcycles in Manado. Journal EMB. 2 (3) : 1255-1263

Tjiptono, Fandy. 2020. Strategi Pemasaran: Prinsip dan Penerapan. Jakarta. Penerbit Andi

Weenas, J.R.S. (2013). Kualitas Produk, Harga, Promosi Dan Kualitas Pelayanan Pengaruhnya Terhadap Keputusan Pembelian Spring Bed Comforta, Jurnal EM-BA, 1 (4): 607-618.

Wibowo, S.F., \& Karimah, M.P. (2012). Pengaruh Iklan Televisi Dan Harga Ter-hadap Keputusan Pembelian Sabun Lux (Survei Pada Pengunjung Mega Bekasi Hy-permall), Jurnal Riset Manajemen Sains Indonesia (JRMSI), 3 
Jurnal Studi Manajemen dan Bisnis Vol. 7 (1) 2020 : 1-13

(1) $17-29$

Widagdo, H. (2011). Analisis Pengaruh Kualitas Layanan Dan Promosi Terhadap Keputusan Konsumen Membeli Komputer Pada PT. XYZ Palembang. In Forum Bisnis Dan Kewirausahaan Jurnal Ilmiah STIE
MDP. $1(1): 1-10$

Wijaya, M.H.P. (2013). Promosi, Citra Merek, Dan Saluran Distribusi Pengaruhnya Terhadap Keputusan Pembelian Jasa Terminix Di Kota Manado, Jurnal EMBA, 1 (4): 105-114. 